\title{
Legal Protection of Good Faith Buyer in Land Sale and Purchase Disputes
}

\author{
Debora Realin Tambunan ${ }^{1}$, Hulman Panjaitan ${ }^{2}$, L. Elly. A.M. Pandiangan ${ }^{3}$ \\ \{realindebora@gmail.com\} \\ Faculty Of Law Universitas Kristen Indonesia
}

\begin{abstract}
Land is such a crucial thing in the social aspect of life and state. In practice, the sale and purchase of land show disputes, especially relating to the good - faith problem, which is becoming the main problem of sale and purchase in Indonesia. This research type is a juridical normative method, whose source is obtained from secondary data. The result indicates that land sale and purchase must be carried out before a notary because an authentic deed has the perfect evidentiary power to get legal certainty. The legal protection form for buyers is provided both preventively and repressively. Preventive legal protection is the formation of statutory regulations which become the basis for conducting the sale and purchase legal acts. Whilst, repressive legal protection is the land dispute settlement, either through litigation or non-litigation.
\end{abstract}

Keywords: Legal protection; sale and purchase; land disputes

\section{Introduction}

Heretofore, the demand for land is increasing. This occurs because of population growth. Also, every aspect of human life is always related to the land, such as a residence, business, and burial. The human desire to control and own land parcels is based on its economic value in all aspects of community life. It has made land buying and selling activities as a form of transfer land rights increases. Buying and selling is a basic economic activity carried out by the community. Based on article 1457 of the Civil Code, sale and purchase is an agreement between the parties that bind each other to fulfil their obligations; namely, the seller surrenders the material, and the buyer hands over the payment. Buying and selling land appears as part of fulfilling the need for land.

Regarding the agreement set out in the Burgelijk Wetbook (B.W), the third book about the engagement where the agreement is consensual in nature and follows an obligatory system (Subekti: 2014). This means that the agreement regulates both parties' rights and obligations. Basically, the parties are given the freedom to make an agreement but still have to fulfil several conditions and parameters that have been determined, namely that it must not conflict with legislation, public order and morality so that the agreement is considered valid.

Through the parties' consensus to bind themselves on goods and prices means that an agreement has been born. The agreement is a law for the person who made it. That means what has been agreed by the parties must be obeyed and carried out by the parties as written in article 1338 paragraph (1) of the Civil Code "all agreements made legally are valid as law for those who make them." The practice of buying and selling must be based on good faith by the parties as according to Article 1338 paragraph (3) of the Civil Code. Good faith is one of the agreement's principles and becomes an essential factor in implementing the sale and purchase. 
Good faith should be applied both in the agreement process and when the agreement is closed (Budiono, Herlien: 2011). The purpose of the agreement can be carried out properly. Buyers who have good faith give complete trust to the opposing party, who is considered honest and conveys what it is to not cause difficulties and problems in the future.

Buying and selling of land is a complex issue. The high value of land and many parties with interest in the land make land problems unavoidable. The fact is, not all the processes of buying and selling land run smoothly. It will make a dispute if one of the parties is default or acts against the law. The problem of buying and selling land that often occurs is that there is no clear information regarding the land being traded or it is not known whether the seller is the legal owner of the land even though the buyer has paid a certain amount of money to the seller. As a result, buyers who have good faith experience losses in the future. Therefore, it needs an indepth study to determine whether the buyer can be said to have good faith or not. Because an honest buyer, of course, must get legal protection.

Based on the large number of land cases involving the transfer of land rights in Indonesia, special handling is needed because it causes losses and the possibility that there could be legal provisions. In this regard, what will be discussed is how the legal protection for buyers with good faith in buying and selling land so that there is legal certainty over the land which is the object of sale and purchase, and the validity of the Sale and Purchase Agreement Deed made before a Notary.

\section{Research Methods}

This research type is a juridical normative method with a statutory approach. That aims to examine the implementation of all legal regulations, including norms and principles related to the legal issue being researched (Marzuki, Peter M.: 2019). Data is collected by using library research with secondary data. The data source used is primary legal material, which is a legal material with binding power for each individual or society, including legislation and jurisprudence. Secondary legal materials, namely legal materials, provide instructions and explanations for primary legal materials such as books and scientific journals. Tertiary legal materials, namely legal materials, provide information and explanations for primary and secondary legal materials such as legal dictionaries and encyclopedias. The qualitative data are analyzed with the descriptive analysis method. Provide a clearer picture of the process of buying and selling land and aspects of legal protection.

\section{Results and Discussion}

\subsection{Legal Aspects of Land Buying and Selling in Indonesia}

The good faith of the parties is required to minimize the occurrence of disputes in the future. According to Black's Law Dictionary, good faith is defined as "in or with good faith, honestly, openly and sincerely, without deceit or fraud truly, actually, without simulation or pretense" (Wiwoho, R.H.: 2017). Good faith means honesty. People with good intentions put complete trust in the opponent, which he considers honest and does not hide anything wrong, which can cause difficulties (Subekti: 2004). Many views about good faith provide flexibility in interpreting goodwill. Someone has good faith if it fulfills the elements of honesty, 
reasonableness and pays attention to others' interests (Abdullah, Nurhaidah: 2004). Good faith prevails throughout the agreement process. Thus, good faith includes three phases: precontractual phase, contractual phase, and post-contractual phase (Hernoko, Agus Y.: 2013; Laila, F., Budiono, A. R., Istislam, I., \& Permadi, I.: 2020).

The procedure for buying and selling land can be done through Land Deed Official (PPAT), auction, and land purchase through underhand. In general, the sale and purchase of land in the community are still carried out under various applicable legal provisions, namely buying and selling according to the provisions of customary law, buying and selling according to the provisions of the Civil Code, and according to the provisions of the Law No. 5 of 1960 on the Basic Regulation of Agrarian Principles which furthermore known as the Basic Agrarian Law (UUPA). However, after enacting UUPA concerning the basic regulations of Agrarian Principles, the dualism of land law in Indonesia was eliminated. So, all processes of transfer of land rights following the UUPA and Government Regulation Number 10 of 1961, including the sale and purchase of land must meet clear, cash, and real requirements.

Clear means that the act of transferring land rights is carried out in the presence of an authorized official. Cash means that the assignment and payment of the price are made at the same time. The price of land that is paid can be paid in full and can also be paid in part. Then real means that by agreeing between the parties, there has been a sale and purchase (Sutedi, Adrian: 2009).

Since the enactment of Government Regulation No. 10 of 1961, which has been amended to Government Regulation No. 24 of 1997 concerning Land Registration, it regulates that the parties carry out the sale and purchase before the Land Deed Official (PPAT) in charge of doing the deeds. It is because the fulfilment of the terms of sale and purchase of land according to Customary Law, namely clear, cash, and real does not guarantee the buyers' right. The sale and purchase of land must comply with the procedure according to the applicable laws. Two conditions must be met in the sale and purchase of land:

\section{Material Requirements}

1. The buyer has the right to buy the land in question

To determine whether the buyer has the right to obtain the land he has bought depends on what rights the land is, whether it is right of ownership or right to build or right to use. According to the UUPA, only single Indonesian citizens and legal entities established by the government can own land rights. This is regulated in article 21 of the UUPA. In Article 26, paragraph (2) of the UUPA, if the buyer has a foreign nationality and Indonesian citizenship, the sale and purchase are cancelled because of the law. Also, the landfall to the state.

2. The seller has the right to sell the land in question

The party entitled to sell a parcel of land is only the land title's legal holder or is called the owner. If the owner of a land plot is only one person, he has the right to sell the land. Nevertheless, if the owner of a plot of land is two or more people, then all those people are entitled to sell the land together. No one is allowed to be a seller.

3. The land rights concerned may be traded and not in dispute.

Based on the provisions of the UUPA, the rights to land that can be traded are property rights (article 20 of UUPA), right to cultivate (article 28 of UUPA), right to build (article 35 of UUPA), and right to use (article 41 of UUPA). Land that is being traded, which is currently in dispute, land that cannot be traded. So that the sale and purchase are considered invalid, and buying and selling of land carried out by those who are not entitled and buying 
and selling of land carried out by those who are not entitled can be canceled because they are related to the subjective conditions in article 1320 of the Civil Code.

\section{Formal Requirements}

Sale and purchase must be carried out by Land Deed Official and must be proven by a Land Deed. To obtain legal certainty for the purchased land and binding on a third party, registration must be carried out (Ginting, D.: 2019). Based on Article 37-point 1 Government Regulation No.24 of 1997 concerning Land Registry, the transfer of rights to land and property rights to apartment units through sale and purchase, exchange, grants for income in companies, and other legal actions of transfer of rights. Except for the transfer of rights through auction can only be registered if proven by a deed drawn up by the authorized Land Deed Official according to the provisions of the prevailing laws and regulations.

The authentic deed is an absolute requirement for the registration of the transfer of rights. If the land is not registered or not controlled by the buyer, it can provide opportunities for those with bad faith to sell the land back to another party (Sumardjono, Maria S. W.: 2009). The sale and purchase of land under the hands have a weakness. Buying and selling under the hand are recognized as a buyer in good faith and is declared legitimate. But, the agreement under the hand has no legal certainty because the private deed and notary deed has different powers of proof.

According to article 1868 of the Civil Code, an authentic deed is a deed made in the form prescribed by law, drawn up by or in front of public officials appointed to do so at the place where the deed was done. So, an authentic deed must fulfill the provisions of Article 1868 completely because if it does not meet the requirements, it cannot be treated as an authentic deed, only has the power as underhand writing. An authentic deed is perfect evidence because they have three kinds of evidentiary powers, namely power of formal proof (they have explained what is written in the deed); the power of material proof (between the parties the incident in the deed had occurred); binding strength (on that date in the deed, the party and the third party have appeared before a public employee and explain what was written in the deed) (Susantio, Retnowulan: 2009).

Even though the agreement's principles and several provisions in the Civil Code, have stipulated in detail the sale and purchase agreement, some provisions cannot be implemented by one of the parties with bad faith and cause harm to the party with good intentions. As a result, there is no legal certainty. Based on guaranteeing legal certainty, order, and protection, written evidence is needed to clearly define the rights and obligations of individuals or legal entities as legal subjects in society.

Moreover, to guarantee the legality of the transfer rights to land, the sale and purchase must be carried out before the notary or Land Deed Official the official authorized to authenticate a sale and purchase. The deed is evidence of a legal act, namely sale and purchase, except for sale and purchase, which is conducted through an auction process under applicable legal provisions.

\subsection{The process of buying and selling land}

Among the indigenous peoples, buying and selling land usually begins deliberations to reach an agreement between the seller and the buyer of the land object being traded and its price. Then, the parties' agreement is followed by the provision of an advance from the buyer to the seller as a sign that the sale and purchase of land will be carried out. Furthermore, the prospective seller and buyer face the local Customary Head and make a deed or letter signed by 
the parties and the customary head to prove the sale and purchase of land between the seller and the buyer (Pramukti, Angger S. \& Erdha W: 2015).

Regarding the procedure for buying and selling land, a distinction is made between land that has not been certified and those that have been certified.

\section{Land that has not been certified}

Land that is not registered or has not been certified as a higher legal risk. Therefore, the object of sale and purchase of land rights that have not been certified emphasizes the principle of prudence. Sales of uncertified land must go through a process of transferring land rights before the authorized official. Before the transfer of rights is carried out, the payment of a predetermined fee must be settled until it is paid off. With the sale and purchase of uncertified land, the evidence is usually in the form of Greek. To ensure the process of transferring rights to land through sale and purchase, it is necessary to make a land deed made by the notary or Land Deed Official. Then registration is carried out at the land office to obtain a certificate to sign that the strongest land right is a certificate. To get a certificate, one must make land registration. Land registration is essential because it ensures legal certainty, legal protection and is carried out in the community and government's interests (Mayore, Fredrik: 2017).

\section{Land that has been certified}

The process of buying and selling land rights that have been registered or certified carries a low legal risk because the ownership rights and legal subjects of the seller are transparent and clear. In the land that has been certified, before there are a sale and purchase deed, the parties concerned must submit the necessary documents to the Land Deed Official, namely if the land has been certified, the original land certificate, and proof of payment of registration fees. Article 40 of Government Regulation No. 24 of 1997 on Land Registration states that after the deed is drawn up, no later than seven days after the deed is signed, the Land Deed Official submits the deed to the land registration office for registration of transfer of rights. as regulated in article 40 Government Regulation No. 24 of 1997 concerning Land Registration.

With the land deed made by the Land Deed Official, there had been a transfer of land rights from the right holder as the seller to another party as the buyer. In order for a third party to know about the sale and purchase, the sale and purchase must be registered at the local land office because the land registration is open. Following are the stages of buying and selling land rights (Hartanto, J. Andy: 2018):

1. Preparation for making land deed

Land Deed Official conducts checks to match data at the land office, ensures that the land is not in dispute, is not collateralized, and is not in confiscation.

2. Preparation and signing of land deed

When making the land deed, the party who commits the legal action must be present, namely the seller and the buyer or a person authorized by them by a written power of attorney under the prevailing laws and regulations. A power of attorney for the seller must be with a notary deed or authentic deed, meanwhile, a power of attorney for the buyer may be made by a private deed.

At the time of signing the sale and purchase deed before Land Deed Official, besides being signed by a notary and/or Land Deed Official and both parties must also be witnessed by at least two witnesses who meet the requirements applicable laws. After the sale and purchase deed contents have been read out and given an explanation by the Land Deed Official, then the deed is signed by the parties, notaries, and witnesses. 


\section{Registration of land deed}

Land Deed Official is obliged to submit the land deed and other documents required for registration of the transfer of rights to the land concerned with the Land Office. Within seven working days from the signing of the deed concerned. Then, the Land Office will give a receipt of the submission of the application for registration of transfer of rights and the authentic deed and other attached documents received to Land Deed Official or its attorney or employee. Suppose the registration application file has been registered and the Land Deed Official has received the receipt of receipt. In that case, the Land Deed Official will notify the buyer regarding submitting the application for registration of transfer of rights to the land office and submitting the buyer. Henceforth, the settlement of the application for registration of transfer of rights is carried out by the buyer or Land Deed Official or other parties on behalf of the buyer.

\section{Submission of land title certificates}

After the new titleholder is registered in the land ownership certificate in the land book and other registers, the land title certificate has been reversed or the change in the name of the new owner of the land title is recorded. Then the land title certificate whose name has been changed from the old right holder to the new right holder by the Head of the Office is handed over to the applicant to register the transfer of land rights to the buyer as the new right holder.

\subsection{Land Disputes Settlement}

Disputes often arise in the process of buying and selling land because of a lawsuit from a person or legal entity whose land rights have been impaired. The material for a lawsuit can be in the form of demands for legal certainty regarding who has the right to land, land status, evidence that forms the basis for granting rights, and others. This land sale and purchase dispute seem endless and always occurs in sectors of community life (Santiago, F.: 2017).

According to data from the Directorate-General for Land Disputes and Conflict Handling, the number of land disputes/conflicts that have been resolved in the $2015-2019$ period is 3,179 cases and the number of land cases that the court has resolved is 3,015 cases. From this typology, cases that often arise are Land Transition Registration, Land Registration, and Rights Establishment, Determination of Borders/Area Plots, and Unregistered Land Control/Ownership (Sudwijanto, Hary: 2020). In 2020, the Minister of Agrarian and Spatial Planning/National Land Agency (ATR/BPN) Sofyan Djalil said 1,228 land dispute cases had to be resolved by BPN (Sofyan: 2021).

In general, land disputes arise due to factors including the following:

a. Incomplete regulations;

b. Regulatory inconsistencies;

c. Land officials who are not responsive to the needs and the amount of land available;

d. Inaccurate and incomplete data; Incorrect soil data;

e. Limited human resources in charge of resolving land disputes;

f. Incorrect land transactions; Act the applicant for the right;

g. There is a settlement from other agencies resulting in overlapping authority (Syarief, Elza: 2012).

A buyer in good faith must receive legal protection from the state. As in jurisprudence or previous judges' decisions as a source of positive law in Indonesia, it can guide law enforcement officials in solving a case. The principles in the previous judge's decision can be applied to determine the criteria for good faith in the sale and purchase of land. As in the Supreme Court Decision No. 251 K/Sip/1958, buyers with good intentions must be protected, and the sale and 
purchase concerned must be considered valid (Panjaitan, Hulman: 2014). Other jurisprudence is Supreme Court Decision No. 1778 K/Pdt/2013. In that decision, buyers with good intentions are protected because there is proof of receipt of money (receipts) acknowledged by both parties, even though the buyer does not have a land deed and a land certificate.

Thus, to prove that the buyer in good faith is as follows:

1. If the sale and purchase's object is customary land or not yet certified, it must meet clear, cash, and real requirements.

2. The sale and purchase of the land must comply with the provisions of the UUPA, Government Regulation No. 24 of 1997, 1338 of the Civil Code (freedom of contract), and 1320 of the Civil Code (validity of sale and purchase)

3. The buyer must comply with the precautionary principle, namely checking physical data (location, area, boundary, building/part of it) and juridical data (information regarding the legal status of the land, such as whether the land is certified or not and what rights the land is).

According to Philips M. Hadjon, the form of legal protection provided can be prevented or repressive. Preventive legal protection aims to prevent disputes. Then repressive protection aims to resolve disputes, including handling them in the judiciary (Hadjon, Philipus M.: 1987; Firmansyah, Ade A.: 2014). Therefore, the existence of legal protection provides an overview of the functioning of the legal function to realize legal objectives, namely justice, benefit, and legal certainty for citizens.

Preventive legal protection is the formation of statutory regulations which become the basis for conducting the sale and purchase legal acts. One form of its implementation is the formation of laws and regulations governing the sale and purchase of land, both through the Civil Code, Laws and Regulations specified in the land sector, stated in UUPA and Government Regulation No. 24 of 1997. At the practical level, the land sale and purchase agreement's implementation can be made in a written sale and purchase agreement. The goal is that if the seller does not fulfill the terms of the agreement, the responsibility can be held. Besides, the presence of witnesses in every agreement is a form of legal protection to minimize risks. The witness's testimony can be used as evidence at trial. Finally, the process of buying and selling land is carried out before the Land Deed Official.

Furthermore, repressive legal protection for buyers with good faith is on dispute resolution. The land dispute settlement in Indonesia can be carried out through litigation and a nonlitigation mechanism called Alternative Dispute Resolution (ADR).

\subsubsection{Litigation Disputes Settlement}

The buyer can file a lawsuit in litigation if the deliberative dispute resolution efforts do not reach a bright spot. The lawsuit can be based on default or an act against the law. The purpose of the lawsuit for default is to put the plaintiffs in a position if the agreement is fulfilled. Thus, the compensation is in the form of the expectation loss. The purpose of a lawsuit against the law is to place the plaintiff's position in its original state before the action against the law took place. That the compensation was given is a reliance loss (Suharnoko: 2015).

In general, the compensation is calculated in a certain amount of money. The existence of an illegal act known in Civil Law as onrechtmatige daad is regulated in Article 1365 of the Civil Code but the claims of compensation, based on onrechtmatige daad, is not regulated in the Civil Code. So that usually claims for compensation ask for material and immaterial damages. There are several forms of prosecution in an illegal act, such as compensation in the form of money, compensation in the form of restoring its original state, a statement that an act was committed against the law, prohibition of committing an act, negating something that was done against the 
law. Meanwhile, a claim for compensation in default is regulated in the Civil Code, which regulates the period for calculating the compensation that can be sued and the type and amount of compensation that can be sued (Mantili, Rai: 2019).

Law No. 2 of 1986 concerning General Courts is regulated regarding the composition, power, and environment of the general court to ensure judicial power implementation in Indonesia. Judicial power within the general court is exercised by:

1. District Court, which is the court of the first instance

2. High Court, which is the court of appeal

3. Judicial power within the general judiciary culminates in the Republic of Indonesia's Supreme Court as the highest court (Syarief, Elza: 2012).

The scope of land disputes submitted in the General Court is regarded as a civil case and a criminal case. Civil disputes inland are disputes relating to civil rights. The main problem relates to the validity of the basis of rights to provide legal certainty. Meanwhile, in a criminal case in the land, there are elements of the crime, both in the Criminal Code and the UUPA.

Then the State Administrative Court has the duty and authority to handle disputes of an administrative nature, namely the object of state administrative decisions. State Administrative Disputes are resolved in two ways as follows:

1. Through administrative efforts, this method is a procedure that can be achieved by a person or a civil legal entity whose approval is dissatisfied with a State Administration decision.

The forms of administrative efforts are:

a. Administrative appeal, namely the administrative settlement carried out by an agency who issued the decision.

b. Objection, namely the settlement of administrative efforts carried out by the State administrative agency or official who issued the decision.

2. Through a lawsuit, the parties, litigating at the State Administrative Court include:

a. Plaintiff, namely a person or civil legal entity who is harmed by the issuance of a State Administrative Decree.

b. Defendants, namely State Administration bodies or officials who issue decisions based on the authority that is in them or delegated to them (Syarief, Elza: 2012).

\subsubsection{Non-litigation Dispute Settlement}

Because of the complexity and the increasing number of land disputes being submitted to the court, they are deemed ineffective. Litigation settlement is supposed to be the last resort (ultimum remedium). According to Maria S. W. Sumardjono, new ideas are needed to take advantage of out-of-court dispute resolution through ADR. Referring to Law Number 48 of 2009 concerning Judicial Power, it has provided a legal basis in terms of choice of law. Article 58 of Law Number 48 of 2009 explains that civil dispute resolution can be carried out outside the court, namely arbitration and alternative dispute resolution.

Under Law No. 30 of 1999 concerning Arbitration and Alternative Dispute Resolution, the process of resolving land disputes through non-litigation can be carried out in the following ways, such as consultation, negotiation, mediation, conciliation, expert assessment, and arbitration. One alternative dispute resolution that can be carried out in the court and outside the court in Indonesia is mediation involving a third party as a mediator to find a win-win solution. (Chandra, T.: (2019).

In non-litigation, land dispute resolution can be made through at National Land Agency (BPN) by the Deputy for the Study and Handling of Land Disputes and Conflict under the Regulation of the Head of BPN No. 3 of 2011 which has been amended to the Regulation of the 
Minister of Agrarian and Spatial Planning/Head of the National Land Agency of the Republic of Indonesia No. 11 of 2016 concerning Settlement of Land Cases.

Based on article 11 paragraph (3) Agrarian Ministerial Regulation No. 11 of 2016 states that disputes or conflicts are under the authority of the ministry, in this case the Ministry of Agrarian Affairs and Spatial Planning, among others: procedural errors in the measurement, mapping and/or area calculation processes, procedural errors in the process of registering and/ or recognizing the rights to land formerly owned by custom, procedural errors in the process of determining and/or registering land rights, procedural errors in the process of determining abandoned land, overlapping rights or certificates of land rights where one of the reasons for the rights is clearly wrong, procedural errors in the process of maintaining land registration data, procedural errors in the process of issuing replacement certificates, errors in providing information on land data, procedural errors in the licensing process, misuse of space utilization, and other errors in the application of laws and regulations.

Apart from these disputes or conflicts, the Ministry of Agrarian Affairs and Spatial Planning cannot handle land cases. However, the Ministry of Agrarian Affairs and Spatial Planning can take the initiative to facilitate dispute or conflict resolution through mediation (Article 12 paragraph (5) Regulation of the Minister of ATR/Head of BPN RI No.11 of 2016). The mediation route in this regulation is also taken for types of disputes or conflicts, both under the ministry's authority or those not under the authority of the ministry.

For example, a land case outside the court related to land legal actions against an administrative law, defect decision/letter is one of the ways to solve it, namely by canceling the land title certificate by BPN by issuing a cancellation decision either as an implementation of a court decision or due to an administrative legal flaw. It's just that BPN can carry out not all land disputes regarding the cancellation of land title certificates. Based on this, the settlement of land disputes by Regulation of the Head of BPN No. 3 of 2011 is considered less effective. This is because the decision letter issued by BPN can be sued again. Individuals or civil legal entities who feel that their interests have been harmed by a decision resulting from administrative efforts through BPN can file a lawsuit again at the State Administrative Court.

\section{Conclusion}

With the transfer of land rights through sale and purchase, it must comply with the civil law provisions and the statutory regulations in the land sector. Also, it needs to be based on good faith. Legitimate buying and selling must be carried out in the presence of a notary and the deed is drawn up. An authentic deed is drawn up to ensure the sale and purchase of legal certainty to minimize future disputes. To bind a third party, land registration must be carried out. Also, the legal protection provided to legal subjects, namely buyers, is both preventive and repressive legal protection. Either through the provisions and policies in the Civil Code and laws and regulations in the land sector. Moreover, through efforts to resolve land disputes.

The community should buy and sell land in front of the authorized official to do the deed, so it becomes perfect evidence in providing legal certainty. The community must also be careful in examining physical and juridical facts before making a sale and purchase to guarantee the transfer of land rights and minimize the occurrence of land disputes. The government needs attention to make the settlement of land disputes out of court more effective so that the settlement of disputes is more effective and efficient to guarantee the legality of ownership of 
land rights. In addition, it is necessary to accelerate government programs in land certification so that there are not many abandoned lands and clear ownership.

\section{References}

[1] Budiono, Herlien.: Ajaran Umum Hukum Perjanjian dan Penerapannya di Bidang Kenotariatan. Citra Aditya Bakti. Bandung. p.136 (2011)

[2] Subekti.: Aneka Perjanjian. PT Citra Aditya Bakti. Bandung. p. 11 (2014)

[3] Marzuki, Peter Mahmud.: Penelitian Hukum. Kencana. Jakarta. p. 133 (2019)

[4] Wiwoho, R.H.: Keadilan Berkontrak. Penaku. Jakarta. p. 362 (2017)

[5] Subekti.: Hukum Perjanjian. Intermasa. Jakarta p. 41 (2004)

[6] Hernoko, Agus Yudha.: Hukum Perjanjian Asas Proporsionalitas dalam Kontrak Komersial. Kencana. Jakarta. p. 136-137 (2013)

[7] Sutedi, Adrian.: Peralihan Hak Atas Tanah dan Pendaftarannya. Sinar Grafika. Jakarta. pp. 76-77 (2009)

[8] Sumardjono, Maria S. W.: Kebijakan Pertanahan Antara Regulasi dan Implementasi. Kompas. Jakarta. p.143 (2009)

[9] Susantio, Retnowulan.: Hukum Acara Perdata dalam Teori dan Praktek. Mandar Maju. Bandung. pp. 67-68 (2009)

[10] Pramukti, Angger S dan Erdha W.: dan Erdha W.: Awas Jangan Beli Tanah Sengketa: Panduan Mengurus Peralihan Hak atas Tanah Secara Aman. Medpress Digital. Yogyakarta. p. 52 (2015)

[11] Hartanto, J. Andy.: Problematika Hukum Jual Beli Tanah Belum Bersertifikat. Aswaja Pressindo. Yogyakarta. p. 85-95 (2018)

[12] Syarief, Elza.: Menuntaskan Sengketa Tanah. Kepustakaan Poluler Gramedia. Jakarta. p. 8 (2012)

[13] Panjaitan, Hulman.: Kumpulan Kaidah Hukum Putusan Mahkamah Agung Republik Indonesia Tahun 1953-2008 Berdasarkan Penggolongannya. Kencana. Jakarta. p. 101 (2014)

[14] Hadjon Philipus M.: Perlindungan Hukum Bagi Rakyat Indoensia. PT. Bina Ilmu. Surabaya. p. 29 (1987)

[15] Suharnoko.: Hukum Perjanjian Teori dan Analisi Kasus. Kencana. Jakarta. p. 112 (2015)

[16] Abdullah, Nurhaidah.: Good Faith in Contractual Performance in Australia. Palgrave Macmillan. pp.194-195

[17] Laila, F., Budiono, A. R., Istislam, I., \& Permadi, I.: Application of Good Faith Principles in Transition and Registration of Land Rights with the Deed of Land Deed Making Officials as the Embodiment of Article 33 Paragprah (3) of the 1945 Constitution. International Journal of Multicultural and Multireligious Understanding, 7(10), pp.44-48 (2020)

[18] Ginting, D. (2019). Legal Status of Land Deed Officers in Land Registration for Preventing Land Disputes in Indonesia. Journal of Innovation, Creativity and Change, 5(2), pp. 981-994 (2019)

[19] Saranaung, Fredrik Mayore.: Peralihan Hak Atas Tanah Melalui Jual Beli Menurut Peraturan Pemerintah Nomor 24 Tahun 1997. Lex Crimen Vol VI. pp. 17 (2017)

[20] Santiago, F.: A Legal Perspective of the Law Enforcement of Land Dispute. European Research Studies, 20(4B), pp.578-587 (2017)

[21] Firmansyah, Ade A.: Legal Protection Pattern Of Indonesia's Land Acquisition Regulation: Towards The Thickest Version Rule Of Law. International Journal of Business and Law, p. 144 (2014)

[22] Chandra, T.: Non-Litigation Process Land Dispute Settlement for Legal Certainty. Substantive Justice International Journal of Law, 2(2), p.177-194 (2019)

[23] Mantili, R.: Tanggung Jawab Renteng Ganti Kerugian Immateril Atas Perbuatan Melawan Hukum Dihubungkan dengan Asas Kepastian Hukum. Jurnal Bina Mulia Hukum, 4(1), pp.88-111. (2019)

[24] Kitab Undang-Undang Hukum Perdata

[25] Undang-Undang Nomor 5 Tahun 1960 Tentang Peraturan Dasar Pokok-Pokok Agraria

[26] Undang-Undang Nomor 30 Tahun 1999 tentang Arbitrase dan Alternatif Penyelesaian Sengketa

[27] Undang-Undang Nomor 48 Tahun 2009 tentang Kekuasaan Kehakiman

[28] Peraturan Pemerintah Nomor 24 Tahun 1997 tentang Pendaftaran Tanah 
[29] Peraturan Kepala BPN No. 3 Tahun 2011 tentang Pengelolaan Pengkajian dan Penanganan Kasus Pertanahan

[30] Peraturan Menteri Agraria dan Tata Ruang/Kepala Badan Pertanahan Nasional Republik Indonesia No. 11 Tahun 2016 tentang Penyelesaian Kasus Pertanahan

[31] Putusan Mahkamah Agung No. $251 \mathrm{~K} / \mathrm{Sip} / 1958$

[32] Putusan Mahkamah Agung No. 1778 K/Pdt/2013

[33] Kementerian ATR/BPN. Cegah Masalah Pertanahan Melalui Pimpinan https://www.atrbpn.go.id/?menu=baca\&kd=i3XKbxqIScX3i+3rG40YZWSP8wHMH6+Ly1iZWFj E2Og+6SxV/5MIqliw/+GB/yjK (2020)

[34] Kementerian ATR/BPN. Presiden Serahkan Sertifikat Tanah Untuk Rakyat Se-Indonesia

[35] https://setkab.go.id/presiden-serahkan-sertifikat-tanah-untuk-rakyat-se-indonesia/ (2021) 